\title{
Seasonal variation of Hemiptera community of a temple pond of Cachar District, Assam, northeastern India
}

\author{
Kankana Das ${ }^{1}$ \& Susmita Gupta ${ }^{2}$ \\ 1,2 Department of Ecology \& Environmental Science, Assam University, Silchar, Assam 788011, India \\ Email: ${ }^{1}$ das_kankana@yahoo.in, ${ }^{2}$ susmita.au@gmail.com (corresponding author)
}

Date of publication (online): 26 September 2012 Date of publication (print): 26 September 2012 ISSN 0974-7907 (online) | 0974-7893 (print)

Editor: R. Ramaniba

Manuscript details:

Ms \# 02724

Received 05 March 2011

Final received 11 May 2012

Finally accepted 24 August 2012

Citation: Das, K. \& S. Gupta (2012). Seasonal variation of Hemiptera community of a temple pond of Cachar District, Assam, northeastern India. Journal of Threatened Taxa 4(11): 3050-3058.

Copyright: (c) Kankana Das \& Susmita Gupta 2012. Creative Commons Attribution 3.0 Unported License. JoTT allows unrestricted use of this article in any medium for non-profit purposes, reproduction and distribution by providing adequate credit to the authors and the source of publication.

Author Details: Kankana Das is a part time research scholar of the Dept. of Ecology and Environmental Science. She teaches Zoology in a Higher Secondary School.

Susmita Gupta is Assistant Professor of the Dept of Ecology and Environmental Science, Assam University, Silchar. Field of research includes Environmental monitoring, Freshwater ecology and biodiversity.

Author Contribution: This paper is a part of the PhD work of Kankana Das. Susmita Gupta is the supervisor.

Acknowledgements: Authors are thankful to the Head, Department of Ecology and Environmental Science, Assam University, Silchar for providing the laboratory facilities. Sincere thanks go to Dr. Animesh Bal, ZSI, Kolkata for his help in identification
Abstract: The study records seven families, 11 genera and 14 species of hemipteran insect community in different seasons in a temple pond near Silchar, Cachar District, Assam, northeastern India. The pond is very rich in macrophytes like Nelumbo nucifera (Water Lotus), Hygrorhiza aristata (Indian Lotus), Cynodon dactylon (Bermuda Grass), Philotria sp. etc. The hemipteran families recorded in the system were Corixidae, Gerridae, Aphididae, Mesoveliidae, Notonectidae, Nepidae and Belostomatidae. The species were Micronecta haliploides, Micronecta (Basileonecta) scutellaris scutellaris (Stål) (Corixidae); Neogerris parvula (Stål), Limnogonus nitidus (Mayr), Tenagogerris sp., Rhagadotarsus sp. (Gerridae); Enithares ciliata (Fabricius), Anisops lundbladiana Landsbury, (Notonectidae); Diplonychus rusticus (Fabricius) and Diplonychus annulatus (Fabricius) (Belostomatidae), Rhopalosiphum nymphaeae (Linnaeus) (Aphididae), Ranatra elongata (Fabricius), Ranatra varipes varipes (Stål) (Nepidae) and Mesovelia vittigera Horváth (Mesoveliidae). The highest population of Hemiptera was recorded during the post-monsoon followed by the pre-monsoon and the monsoon periods. The lowest was recorded in the winter. Shannon Weiner diversity index $\left(\mathrm{H}^{\prime}\right)$ and evenness index $\left(\mathrm{J}^{\prime}\right)$ showed the highest diversity and evenness during the post monsoon period. Berger Parker index of dominance (d) was found highest in winter. In winter both diversity and density were the lowest. The study revealed the presence of four dominant species and three sub-dominant species in the pond. Insect diversity did not show any significant relationship with the environmental variables.

Keywords: Density, diversity, Hemiptera, monsoon, post-monsoon, pre-monsoon, winter.

\section{INTRODUCTION}

Aquatic biodiversity is one of the most essential characteristics of an aquatic ecosystem for maintaining stability and a means of coping with any environmental change (Vinson \& Hawkins 1998). Aquatic hemipterans stand out as an important group of aquatic insects, which are considered important in environmental reclamation of aquatic habitats and are often used to gauge toxins in an environment (Jansson 1987; Papacek 2001; Wollmann 2001). They are also considered important fish food and many fishing lures are modeled after aquatic hemipterans (McCafferty 1981).

Studies on aquatic hemipterans in the ponds and wetlands of Assam are very few (Chetri et al. 1997; Majumdar \& Gupta 2004; Kalita 2008; Das \& Gupta 2010) and from southern Assam there are only two published works. This study attempts to understand the temporal variation of the Hemiptera insect community of a temple pond, a 200-year old permanent system situated within a tea estate near Silchar City of Cachar District, Assam along with the physico-chemical properties of the water of the pond (Fig. 1). Further it is essential to know the status of the ecosystem since the temple pond is a sacred one for the people of the locality and is used for religious activities. As pollution status of water bodies are expressed as biological and physico-chemical parameters (Lenat et 
al. 1980), the results of this study can be of use for successful management of the pond.

\section{MATERIALS AND METHODS}

The Bharambaba Temple pond $\left(24^{0} 27^{\prime} \mathrm{N}\right.$ \& $25^{\circ} 08^{\prime} \mathrm{E}$ ) is very close to the quarters of Silcoorie Tea Estate near Silchar City of Cachar District, Assam. The pond is adjacent to the temple facing the highway on one side and the back of the temple on the other side. The system is mainly covered by macrophytes like Nelumbo nucifera (Water Lotus), Hygrorhiza aristata (Indian Lotus), Cynodon dactylon (Bermuda Grass), Philotria sp. etc. The insects were collected in the pre-monsoon (March-May), monsoon (June-August), post-monsoon (September-November) and in winter (December-February) by the Kick method (during March 2007 to February 2008), whereby the vegetation was disturbed and a circular net (mesh size $60 \mu \mathrm{m}$ ) was dragged around the vegetation for one minute (Brittain 1974; Subramanian \& Sivaramakrishnan 2007). Three such drags constituted a sample. Collected insects were immediately sorted and preserved in $70 \%$ ethyl alcohol. They were later identified using Dewinter Advance Stereozoom Microscope with the help of standard keys (Bal \& Basu 1994a,b; Thirumalai 1994, 2007; ZSI 2004) and with the help of experts from the Zoological Survey of India. Meteorological data were obtained from the Meteorological Department, Silchar. During each sampling water sample was also collected for estimating physico-chemical properties of water such as water temperature (WT), transparency, $\mathrm{pH}$, electrical conductivity (EC), dissolved oxygen (DO), total alkalinity (TA), free $\mathrm{CO}_{2}$, total dissolved solid (TDS), and total suspended solids (TSS). They were estimated by the standard methods (APHA 2005). The diversity indices namely Shannon-Weiner and Berger-Parker index of dominance were worked out by Biodiversity Professional V. 2.0. The statistical analysis was done by SPSS V. 12.0.

\section{RESULTS AND DISCUSSION}

The present study recorded seven families, 11 genera and 14 species of the order Hemiptera in the pond. The families were Corixidae, Gerridae, Aphididae, Mesoveliidae, Notonectidae, Nepidae and Belostomatidae. The species were Micronecta haliploides, Micronecta (Basileonecta) scutellaris scutellaris (Stål) (Corixidae); Neogerris parvula (Stål), Limnogonus nitidus (Mayr), Tenagogerris sp., Rhagadotarsus sp. (Gerridae); Enithares ciliata (Fabricius), Anisops lundbladiana Landsbury, (Notonectidae); Diplonychus rusticus (Fabricius), Diplonychus annulatus (Fabricius) (Belostomatidae); Ranatra elongata (Fabricius), Ranatra varipes varipes Stål (Nepidae); Mesovelia vittigera Horvath (Mesoveliidae); Rhopalosiphum nymphaeae (Linnaeus)(Aphididae). The highest population of Hemiptera was recorded in the post-monsoon followed

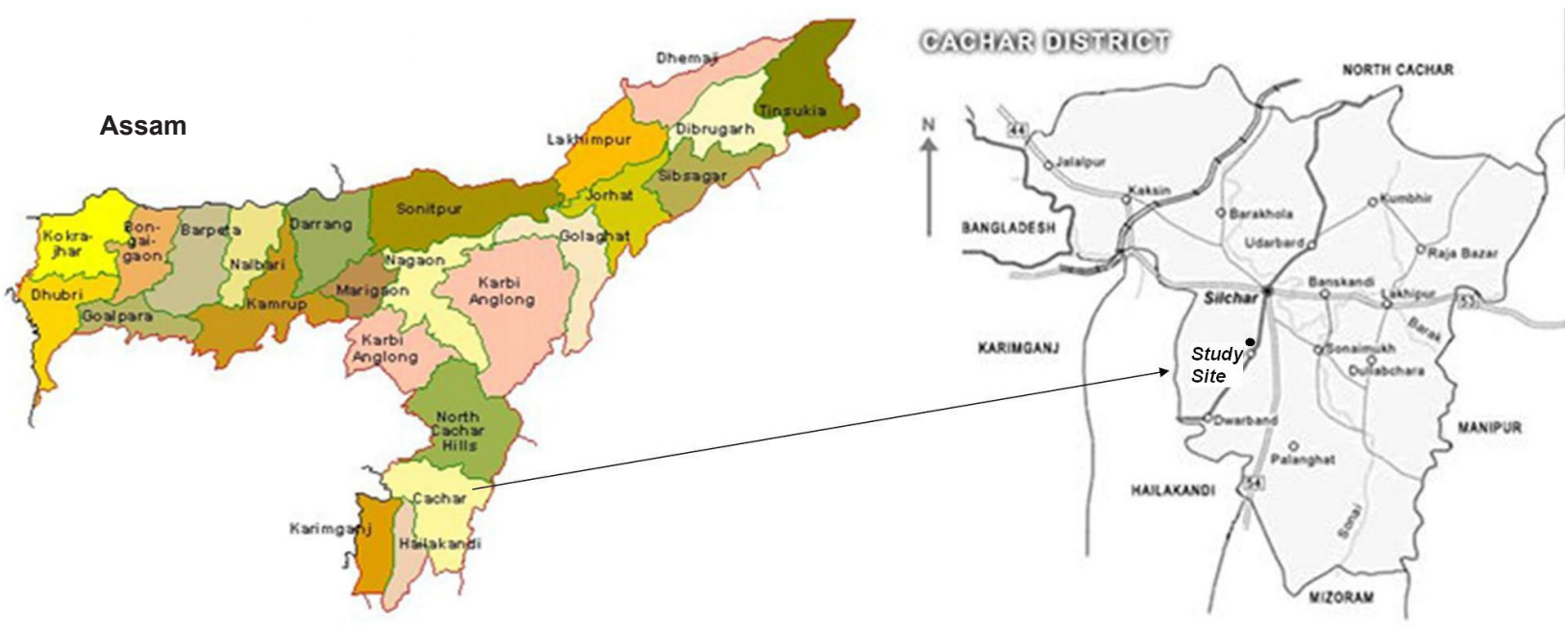

Figure 1. Map of Cachar District, Assam, India showing the location of the Bharambaba temple pond 
by monsoon and pre-monsoon (Fig. 2). Since in winter, the quantity of water in the system is reduced and the peripheral area of the system dries up, the effluents released from the neighbouring factories may have affected the insect density.

The study revealed the presence of the highest number of families (7) in the post-monsoon and the lowest in winter (4). Among all the hemipteran families in all the seasons, the highest population of Hemiptera belonged to the family Notonectidae in the post monsoon and the same family dominated the community in all other seasons except during the monsoon, when Corixidae was the highest in number followed by Notonectidae. Across the seasons either of the two families dominated. This might be due to their ubiquity and abundance in temporary and permanent pools (Eitam et al. 2002). Further they are tolerant to chemical and biological stress and are typically capable of surviving in any permanent water. According to Wollmann (2001) the family Corixidae has been found to have an amazing ability to survive in polluted waters. Aphididae, although present throughout the year, were recorded in large numbers only in the postmonsoon season on the leaves of Nelumbo nucifera (Water Lotus). The population of Belostomatidae was the lowest in all the seasons except the post monsoon where it was replaced by Nepidae, recorded only in that season in very low numbers (Fig. 3).

Ravera (2001) and Sandin \& Johnson (2000) were of the view that diversity and biotic indices may be influenced by any stresses, including pollution. Ludwig

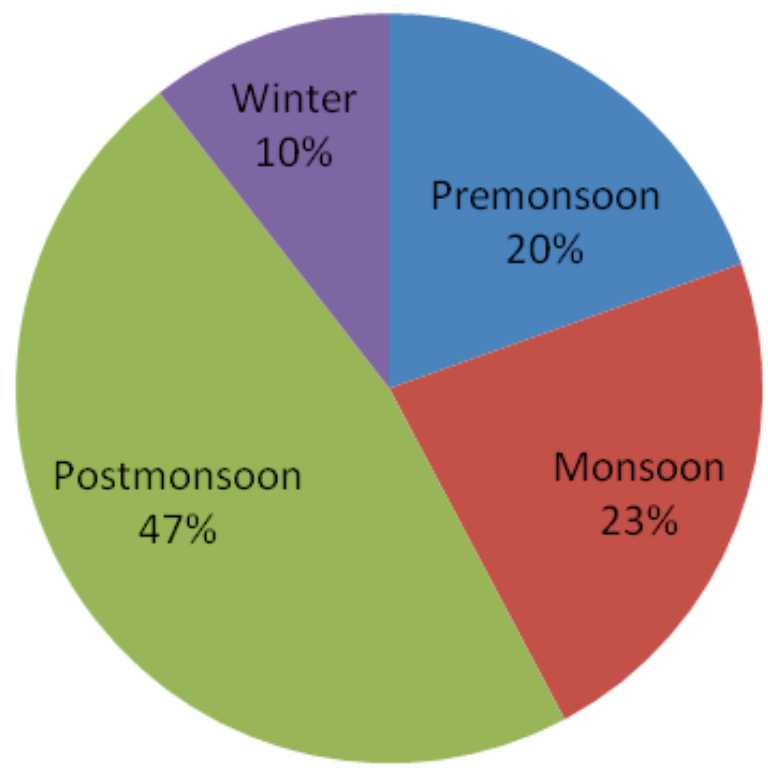

Figure 2. Seasonal variation of Hemiptera population in percentage

\& Reynolds (1988) opined that the total number of species and evenness are two distinct components of diversity. In the temple pond the highest number of species were recorded in the post-monsoon (14) followed by monsoon (10), pre-monsoon (9) and winter (7) (Fig. 4). The study revealed that in all the seasons diversity index values $\left(\mathrm{H}^{\prime}\right)$ were always less than one and the highest Shannon Weiner $\left(\mathrm{H}^{\prime}\right)$ diversity index was recorded in the post-monsoon. Highest evenness index $\left(\mathrm{J}^{\prime}\right)$ and Berger Parker index of dominance was recorded in the pre-monsoon and winter, respectively

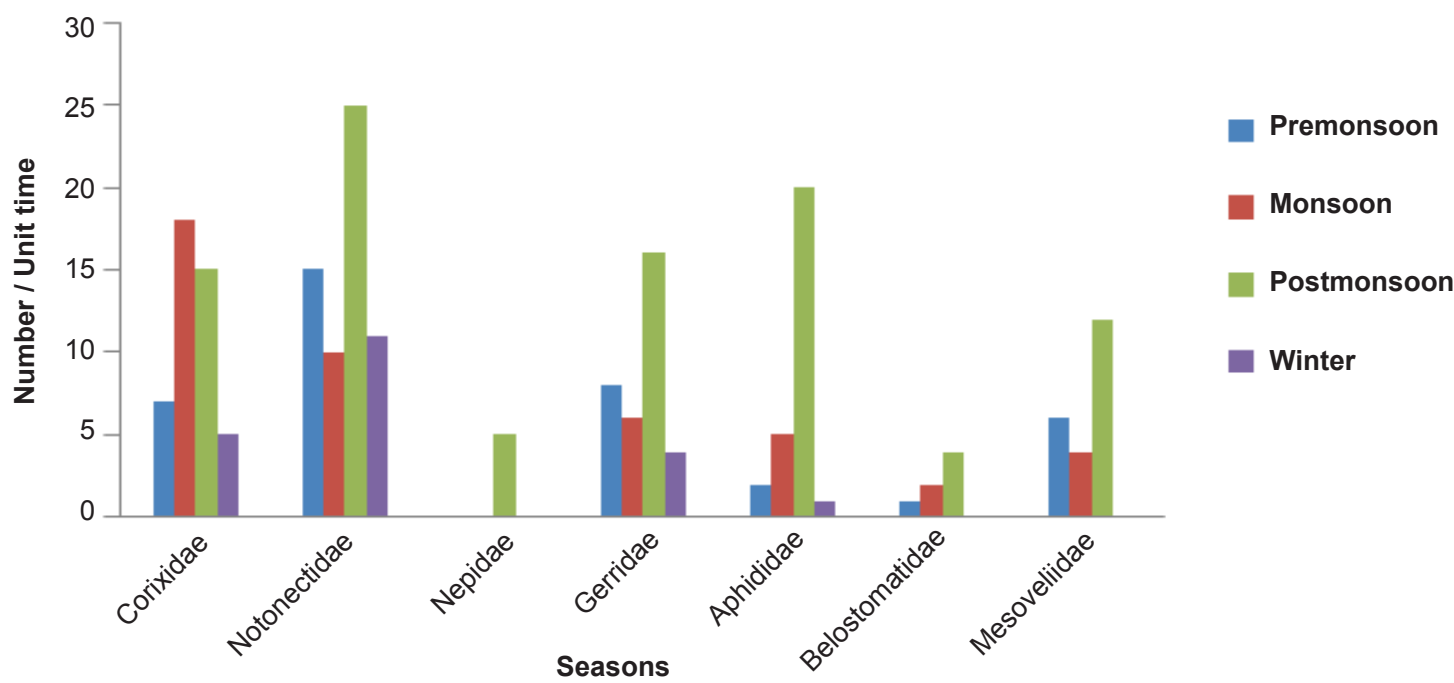

Figure 3. Seasonal variation of density of different Hemiptera families 
(Table 1).

According to Engelmann's Scale (Engelmann 1978) the dominant species of the pond were Micronecta haliploides, Anisops lundbladiana Landsbury, Rhopalosiphum nymphaeae (Linnaeus) and Mesovelia vittigera Horvath followed by subdominant species Micronecta (Basileonecta) scutellaris scutellaris (Stål ), Neogerris parvula (Stål), and Rhagadotarsus sp. Others were recedent species i.e the value of their relative abundance was within the range 1.1-3.1. The number of dominant species in the pond was four out of 14 species of the same order (Table 2). A similar study made on a pond of Midnapore Town of West Bengal found only one dominant species out of 20 species of different orders (Jana et al. 2009).

This study clearly depicted dominance of different species in different seasons indicating temporal niche separation. In the post-monsoon the density of Rhopalosiphum nymphaeae (Linnaeus) was found to be the highest, closely followed by Enithares ciliata (Fabricius). While in the monsoon the density of Micronecta scutellaris scutellaris (Stal) was the highest, in the pre-monsoon and winter Anisops lundbladiana Landsbury was the highest (Fig. 4). In the post monsoon period simultaneous dominant occurrence of two species Rhopalosiphum nymphaeae (Linnaeus) and Enithares ciliata was possible due to their different food choices. Rhopalosiphum nymphaeae (Linnaeus) is a polyphagus species feeding on a variety of host plants and Enithares ciliata is an aggressive predator. It is known that insects of the family Notonectidae are predators and attack many pelagic and benthic invertebrates including their own larvae (Cooper et al. 1985; Giller 1986). In the present investigation special attention was drawn to Rhopalosiphum nymphaeae (Linnaeus) found on the leaves of Nelumbo nucifera, which is otherwise not very common in this region. It was recorded in all the seasons in the pond and in the post monsoon period it was abundant. In a few studies on the aquatic hemipterans in Brahmaputra Valley, Assam (Chetri et al. 1997; Kalita 2008; Hazarika \& Goswami 2010) Rhopalosiphum nymphaeae (Linnaeus) was recorded by Kalita (2008) in Deepor Beel, a Ramsar site in Assam.

Investigations on the environmental variables, revealed that air temperature and water temperature ranged from 28.10 to $33^{\circ} \mathrm{C}$ and 25.11 to $31.04^{\circ} \mathrm{C}$, respectively, in different seasons. While $\mathrm{pH}$ varied from 4.42 to 7.24 , total alkalinity varied from 60.54 to $65.78 \mathrm{mgl}^{-1}$ and free $\mathrm{CO}_{2}$ varied from 9.58 to 11.79 $\mathrm{mgl}^{-1}$. Highest DO $\left(8.22 \mathrm{mgl}^{-1}\right)$ was recorded in the pre-monsoon and the lowest $\left(6.06 \mathrm{mgl}^{-1}\right)$ in winter. A similar range of DO was recorded in a study made by Narayan et al. (2007) in a temple pond in district Etawah (UP). Lowest DO in winter might be due to

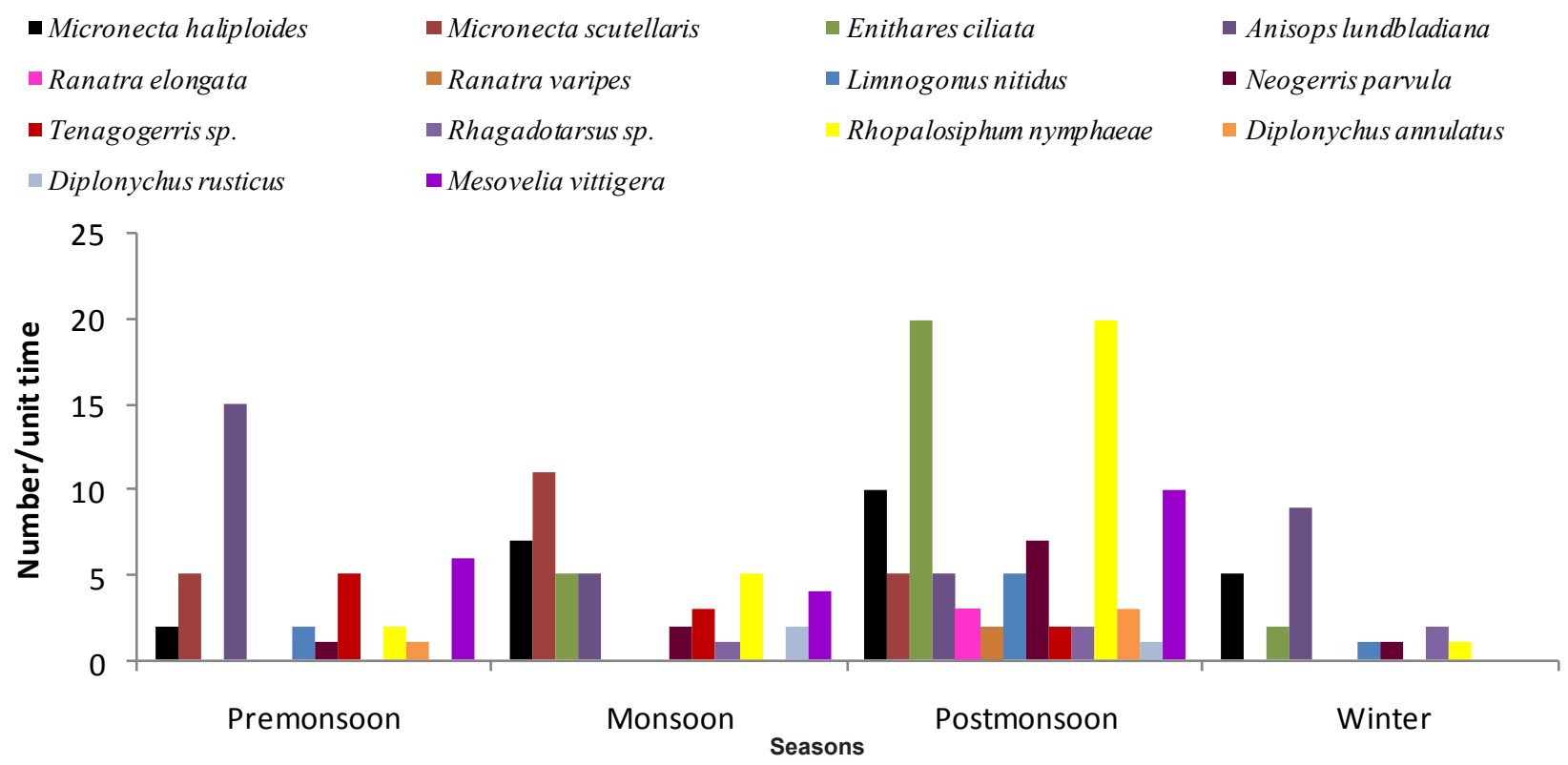

Figure 4. Seasonal variation in density of different species of Hemiptera 
Table 1. Diversity Indices of Hemiptera in four different seasons

\begin{tabular}{|l|c|c|c|c|}
\hline Indices & Premonsoon & Monsoon & Post monsoon & Winter \\
\hline Shannon H' Log base 10 & 0.728 & 0.736 & 0.822 & 0.642 \\
\hline Shannon H max Log base 10 & 0.778 & 0.845 & 0.954 & 0.699 \\
\hline Shannon J' & 0.936 & 0.871 & 0.861 & 0.919 \\
\hline Barger-parker Dominance (d) & 0.294 & 0.343 & 0.293 & 0.385 \\
\hline Barger-parker Dominance(1/d) & 3.4 & 2.917 & 3.417 & 2.6 \\
\hline Barger-parker Dominance (\%) & 29.412 & 34.286 & 29.268 & 38.462 \\
\hline
\end{tabular}

Table-2. Dominance status of different species of Hemiptera community RA <1-Subrecedent; 1.1-3.1-Recedent; 3.2-10-Subdominant; 10.1-31.6-Dominant

\begin{tabular}{|c|c|c|c|}
\hline Taxa & $\begin{array}{l}\text { Number during entire } \\
\text { period of observation }\end{array}$ & $\begin{array}{l}\text { Relative abundance } \\
\text { (\%) }\end{array}$ & Status \\
\hline $\begin{array}{l}\text { Hemiptera } \\
\text { Family: Corixidae } \\
\text { Micronecta haliploides (Image 1) } \\
\text { Micronecta (Basileonecta) scutellaris scutellaris (Stal) } \\
\text { (Image 2) }\end{array}$ & $\begin{array}{l}34 \\
21\end{array}$ & $\begin{array}{l}16 \\
10\end{array}$ & $\begin{array}{l}\text { Dominant } \\
\text { Subdominant }\end{array}$ \\
\hline $\begin{array}{l}\text { Family: Notonectidae } \\
\text { Enithares ciliata (Fabricius) (Image 3) } \\
\text { Anisops Iundbladiana Landsbury (Image 4) }\end{array}$ & $\begin{array}{c}5 \\
56\end{array}$ & $\begin{array}{c}2 \\
27\end{array}$ & $\begin{array}{l}\text { Recedent } \\
\text { Dominant }\end{array}$ \\
\hline $\begin{array}{l}\text { Family: Nepidae } \\
\text { Ranatra elongata Fabricius (Image 5) } \\
\text { Ranatra varipes varipes Stal (Image 6) }\end{array}$ & $\begin{array}{l}3 \\
2\end{array}$ & $\begin{array}{l}1 \\
1\end{array}$ & $\begin{array}{l}\text { Recedent } \\
\text { Recedent }\end{array}$ \\
\hline $\begin{array}{l}\text { Family:Gerridae } \\
\text { Limnogonus (Limnogonus) nitidus(Mayr) (Image 7) } \\
\text { Neogerris parvula (Stal) (Image 8) } \\
\text { Tenagogerris sp. (Image 9) } \\
\text { Rhagadotarsus sp. (Image 10) }\end{array}$ & $\begin{array}{c}6 \\
10 \\
7 \\
9\end{array}$ & $\begin{array}{l}3 \\
5 \\
3 \\
4\end{array}$ & $\begin{array}{l}\text { Recedent } \\
\text { Subdominant } \\
\text { Recedent } \\
\text { Subdominant }\end{array}$ \\
\hline $\begin{array}{l}\text { Family: Aphididae } \\
\text { Rhopalosiphum nymphaeae( Linnaeus) (Image 11) }\end{array}$ & 29 & 14 & Dominant \\
\hline $\begin{array}{l}\text { Family: Belostomatidae } \\
\text { Diplonychus annulatus (Fabricius) (Image 12) } \\
\text { Diplonychus rusticus (Fabricius) (Images 13 \& 14) }\end{array}$ & $\begin{array}{l}4 \\
2\end{array}$ & $\begin{array}{l}2 \\
1\end{array}$ & $\begin{array}{l}\text { Recedent } \\
\text { Recedent }\end{array}$ \\
\hline $\begin{array}{l}\text { Family: Mesoveliidae } \\
\text { Mesovelia vittigera Horvath (Image 15) }\end{array}$ & 22 & 11 & Dominant \\
\hline
\end{tabular}

decomposition of macrophytes present in the edges of the pond due to lowering of the water level. Rainfall showed significant positive relationship with $\mathrm{WT}, \mathrm{pH}$ and negative relationship with DO. A similar significant negative relationship was recorded in a previous study in a floodplain lake of the same area (Laskar \& Gupta 2009). Inverse relationship of DO with rainfall is because of the entry of surface runoff which is likely to carry fertlizers and organic residues from the agricultural fields in the catchment. According to Singhal et al. (1986) during the monsoon surface runoff carries waste and sewage from the surrounding areas into the low lying beds of the floodplain lakes, thereby increasing the respiratory activity of the heterotrophic organisms and lowering the DO concentration of the water. TSS was highest $\left(21.34 \mathrm{mgl}^{-1}\right)$ in the monsoon and always less than the TDS $\left(23.12-42.12 \mathrm{mgl}^{-1}\right)$ in all the seasons which conformed to the fact that in most natural waters TSS is always less than TDS ( Moss 1980) (Table 3 \& 4).

No significant correlations of insect diversity with any of the environmental variables throughout the study period could be recorded. Insect density also showed a similar pattern except one record of significant negative relationship with free $\mathrm{CO}_{2}$. All these can be explained by the fact that life of hemipterans do not depend entirely on water quality (Mackie 2001). As vegetation richness increases with wetland age (Mulhouse \& Galatowitch 2003; Jahr \& Crow 2005), the 200 year old pond has nurtured a rich variety of macrophytes. As hemipterans are known to feed on phytoplankton, zooplankton, insects, and 
Table 3. Seasonal variation of physico-chemical characteristics (Mean \pm SD) of water of the pond.

\begin{tabular}{|l|c|c|c|c|}
\hline Parameters & Pre monsoon & Monsoon & Post monsoon & Winter \\
\hline AT $\left({ }^{\circ} \mathrm{C}\right)$ & $30.0 \pm 2.31$ & $33.00 \pm 1.06$ & $31.11 \pm 0.24$ & $28.10 \pm 1.09$ \\
\hline $\mathrm{WT}\left({ }^{\circ} \mathrm{C}\right)$ & $28.90 \pm 2.12$ & $30.32 \pm 1.25$ & $31.04 \pm 0.21$ & $25.11 \pm 1.90$ \\
\hline Rainfall Data $(\mathrm{mm})$ & $122.4 \pm 17.4$ & $426.2 \pm 26.1$ & $181.0 \pm 13.5$ & $0.29 \pm 0.44$ \\
\hline $\mathrm{pH}$ & $7.08 \pm 0.14$ & $7.24 \pm 0.05$ & $5.36 \pm 0.05$ & $4.42 \pm 0.41$ \\
\hline $\mathrm{TA}\left(\mathrm{mgl}^{-1)}\right.$ & $65.78 \pm 1.73$ & $60.54 \pm 0.54$ & $64.49 \pm 0.43$ & $60.59 \pm 0.69$ \\
\hline $\mathrm{DO}\left(\mathrm{mgl}^{-1)}\right.$ & $7.22 \pm 0.22$ & $8.43 \pm 0.48$ & $7.0 \pm 0.13$ & $6.06 \pm 0.12$ \\
\hline FreeCO2 $\left(\mathrm{mgl}^{-1}\right)$ & $11.09 \pm 0.11$ & $10.01 \pm 0.55$ & $9.58 \pm 0.42$ & $11.79 \pm 0.60$ \\
\hline EC $\left(\mu \mathrm{S}^{-\mathrm{cm})}\right.$ & $1430.1 \pm 0.35$ & $1110.0 \pm 0.11$ & $1200.11 \pm 1.48$ & $721.0 \pm 0.98$ \\
\hline TDS $\left(\mathrm{mgl}^{-1}\right)$ & $42.12 \pm 2.11$ & $23.12 \pm 1.90$ & $34.12 \pm 0.33$ & $26.01 \pm$ \\
\hline TSS $\left(\mathrm{mgl}^{-1}\right)$ & $10.7 \pm 1.09$ & $21.34 \pm 2.12$ & $12.8 \pm 0.89$ & $21.1 \pm 1.0$ \\
\hline Transparency $(\mathrm{cm})$ & $20.1 \pm 1.09$ & $21.90 \pm 0.12$ & $18.90 \pm 2.62$ & $16.04 \pm 1.90$ \\
\hline
\end{tabular}

AT - Air temperature; WT - Water temperature; DO - Dissolved oxygen; EC - Electrical conductivity; TDS - Total dissolved solids; TSS - Total suspended solids; TR - Transparency

Table 4. Correlation coefficient matrix of environmental variables, diversity, and density of Hemiptera in the pond

\begin{tabular}{|l|c|c|c|c|c|c|c|c|c|c|c|c|}
\hline & WT & Rainfall & $\mathbf{p H}$ & TA & DO & Free $\mathrm{CO}_{2}$ & EC & TDS & TSS & TR & Density & Diversity \\
\hline AT & $0.970^{* *}$ & 0.575 & $0.828^{* *}$ & 0.191 & 0.277 & $0.806^{* *}$ & -0.281 & 0.394 & -0.270 & $0.725^{*}$ & -0.060 & 0.408 \\
\hline WT & & $0.676^{*}$ & $0.897^{* *}$ & -0.244 & $-0.868^{* *}$ & -0.293 & -0.466 & 0.325 & -0.182 & $0.695^{*}$ & 0.023 & 0.419 \\
\hline Rainfall & & & $0.677^{*}$ & $-0.740^{*}$ & $-0.733^{* *}$ & -0.420 & -0.365 & -0.055 & 0.054 & 0.510 & 0.259 & 0.469 \\
\hline pH & & & & $-0.740^{*}$ & 0.183 & $-0.955^{* *}$ & -0.129 & -0.410 & 0.278 & -0.153 & 0.469 & 0.044 \\
\hline TA & & & & & -0.353 & -0.066 & $0.896^{* *}$ & $-0.895^{* *}$ & 0.441 & 0.007 & 0.460 & -0.006 \\
\hline DO & & & & & & 0.490 & 0.212 & -0.332 & 0.303 & $0.635^{*}$ & 0.016 & 0.298 \\
\hline Free CO & & & & & & & 0.071 & -0.106 & -0.460 & -0.274 & $-0.712^{* *}$ & -0.390 \\
\hline EC & & & & & & & & -0.092 & 0.090 & -0.173 & -0.310 & -0.191 \\
\hline TDS & & & & & & & & & -0.768 & -0.057 & 0.187 & 0.032 \\
\hline TSS & & & & & & & & & & -0.044 & -0.567 & -0.039 \\
\hline TR & & & & & & & & & & & -0.030 & -0.038 \\
\hline Density & & & & & & & & & & & & 0.178 \\
\hline
\end{tabular}

${ }^{*}=$ Correlation is significant at the $\mathrm{P}<0.05$ level (2-tailed); ${ }^{*}=$ Correlation is significant at the $\mathrm{P}<0.01$ level (2-tailed)

AT - Air temperature; WT - Water temperature; DO - Dissolved oxygen; EC - Electrical conductivity; TDS - Total dissolved solid; TSS - Total suspended solid; TR - Transparency

small vertebrates (Gilbert \& Burns 1999; Hampton et al. 2000), it can be said that these macrophytes with increased habitat structural complexities have provided additional food and living space within the water column for different species.

\section{REFERENCE}

APHA (2005). Standard Methods for the Examination of Water and Wastewater, $21^{\text {st }}$ Edition. APHA, AWWA, WPCF Washington DC, USA, 1200pp.

Bal,A.\& R.C. Basu (1994a). Insecta: Hemiptera: Mesoveliidae,
Hydrometridae, Veliidae, and Gerridae, pp. 511-534. In: Fauna of West Bengal, State fauna series 5, India.

Bal,A. \& R.C. Basu (1994 b). Insecta: Hemiptera: Mesovelidae, Hydrometridae, Veliidae and Gerridae, pp. 535-558. In: State Fauna Series 5, Fauna of West Bengal, India

Brittain, J.E. (1974). Studies on the lentic Ephemeroptera and Plecoptera of southern Norway. Norsk Entomologisk forening 21: 135-151

Chetri, G., M.S. Sheikh, J. Kalita \& A. Dutta (1997). Population abundance of aquatic insects in Deepar Beel Assam. Insect Environment 3(1): 14-15.

Cooper, S.D., DW. Smith \& J.R. Bence (1985). Prey selection by freshwater predators with different foraging strategies. Canadian Journal of Fishery and Aquatic Sciences 42: 


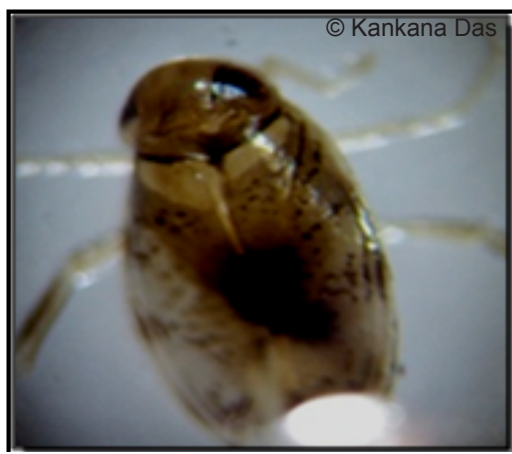

Image 1. Micronecta haliploides

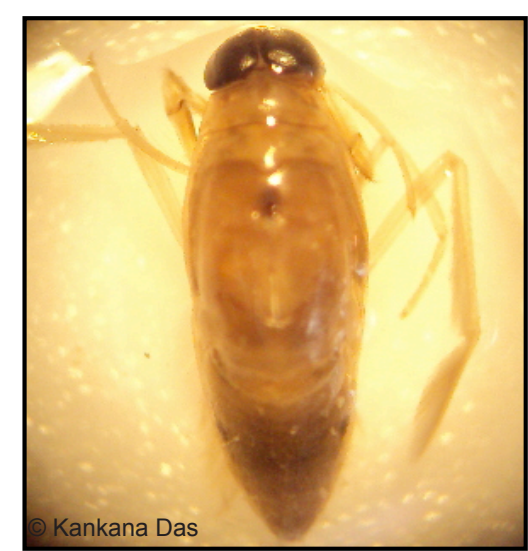

Image 4. Anisops lundbladiana

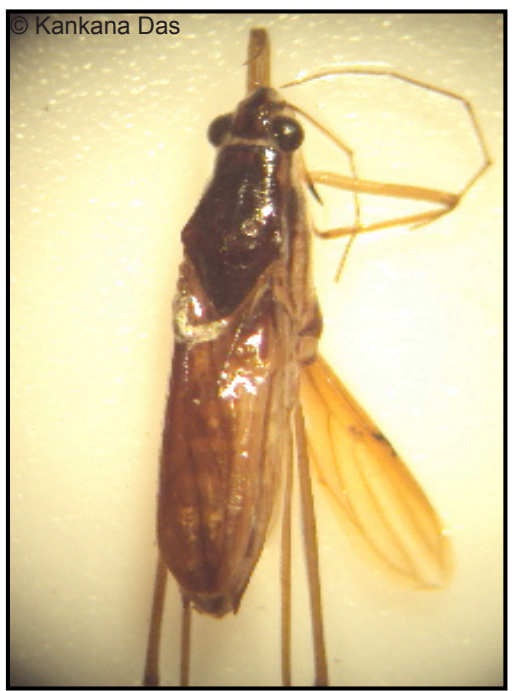

Image 7. Limnogonus nitidus (Mayr)

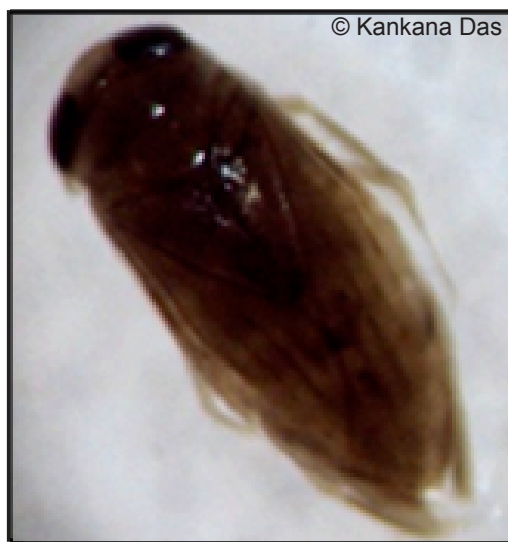

Image 2. Micronecta scutellaris scutellaris

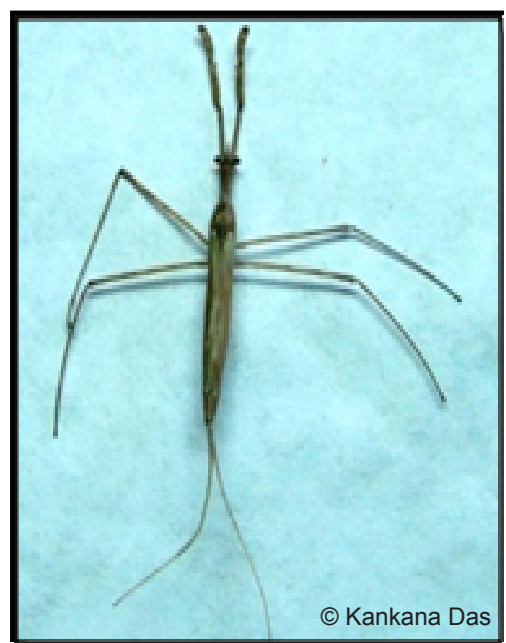

Image 5. Ranatra elongata

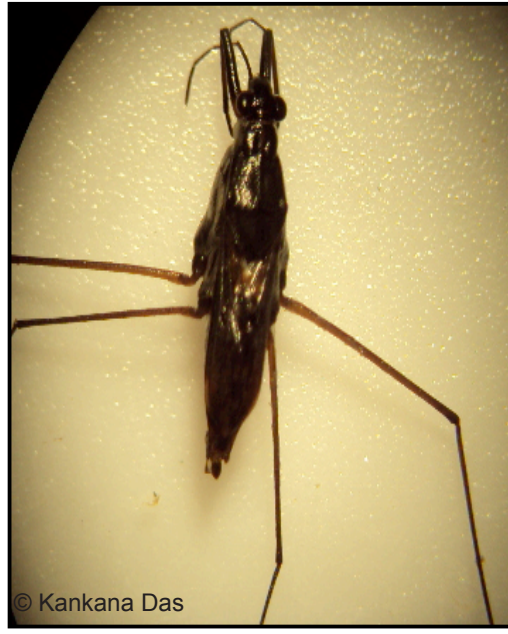

Image 8. Neogerris parvula (stal)

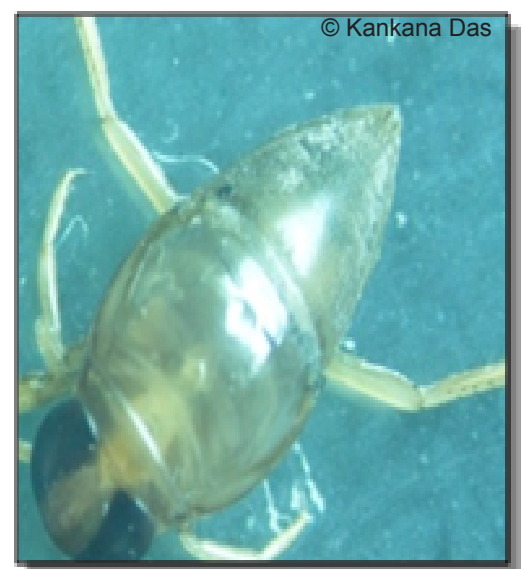

Image 3. Enithares ciliata

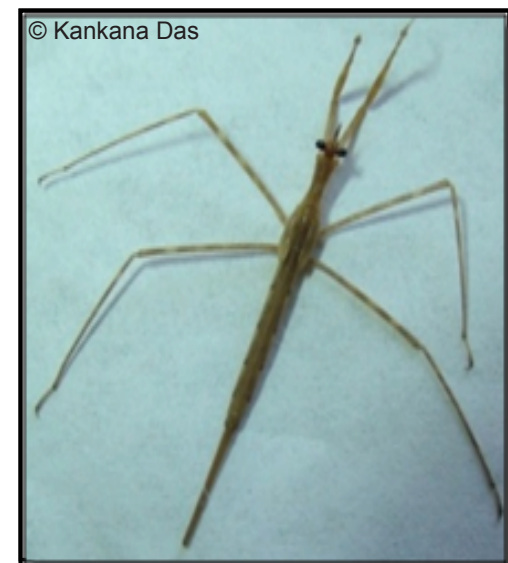

Image 6. Ranatra varipes

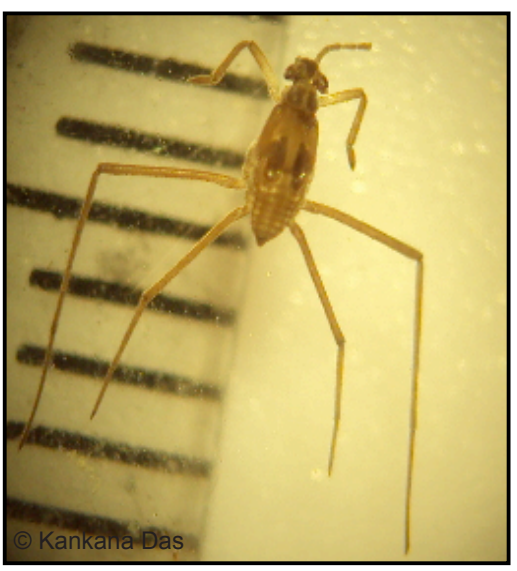

Image 9.Tenagogerris sp. 


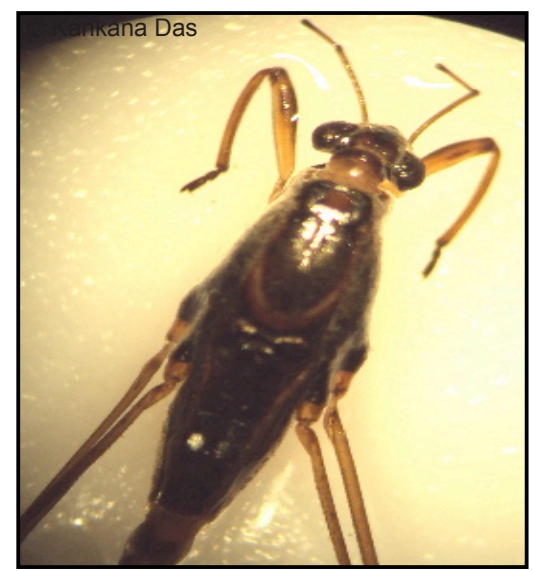

Image 10. Rhagadotarsus sp.

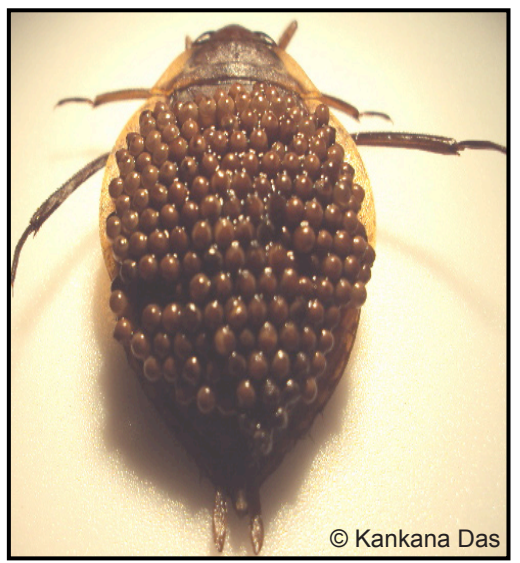

Image 13. Diplonychus rusticus (with eggs)

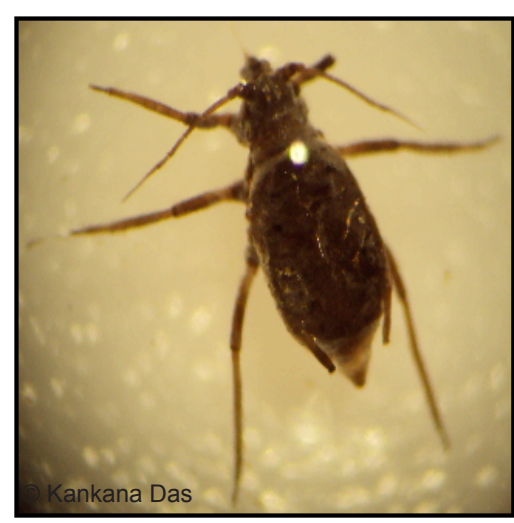

Imgae 11. Rhopalosiphum nymphaeae

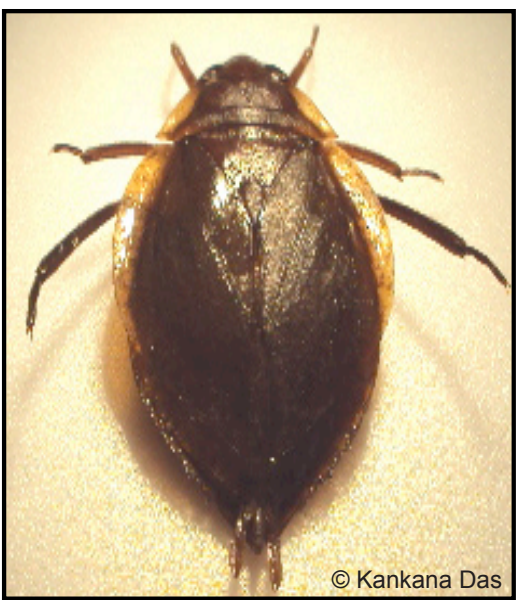

Image 14. Diplonychus rusticus (without eggs)

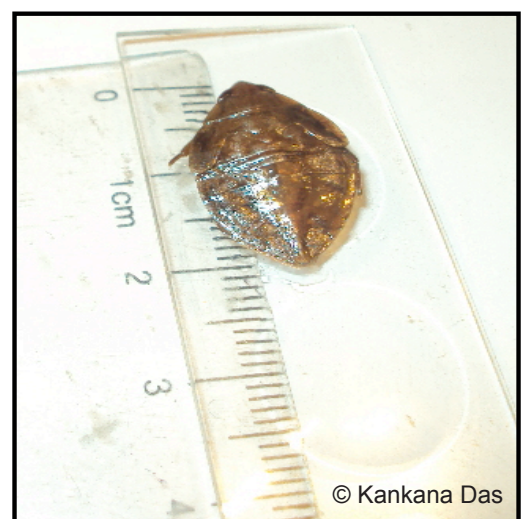

Image 12. Diplonychus annulatus

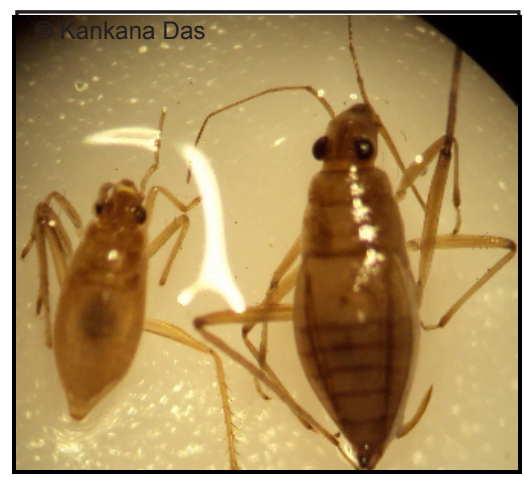

Image 15. Mesovelia vittigera (male and female)
$1720-1732$

Das, K. \& S.Gupta (2010). Aquatic Hemiptera community of agricultural field and rain pools in Cachar District, Assam, North East India. Assam University Journal of Science and Technology 5(1): 123-128.

Eitam, A., L. Blaustein \& M. Mangel (2002). Effects of Anisops sardea (Hemiptera: Notonectidae) on oviposition habitat selection by mosquitoes and other dipterans and on community structure in artificial pools. Hydrobiologia 485: 183-189.

Engelmann, H.D. (1978). Zur Dominanzklassifikazierung von Bodenarthropoden. Pedobilogia 18: 378-380

Gilbert, J.J. \& C.W. Burns (1999). Some observations on the diet of the backswimmer Anisops wakefieldi (Hemiptera: Notonectidae). Hydrobiologia 412: 111-118.

Giller, P.S. (1986). The natural diet of the Notonectidae: field trials using electrophoresis. Ecological Entomology 11: 163-172.

Hampton, S.E., J.J. Gilbert \& C.W. Burns (2000). Direct and indirect effects of juvenile Buenoa macrotibialis (Hemiptera: Notonectidae) on the zooplankton of a shallow pond. Limnology Oceanography 45: 1006-1012.

Hazarika, R. \& M.M. Goswami (2010). Aquatic Hemiptera of Gauhati University, Guwahati, Assam, India. Journal of Threatened Taxa 2(3): 778-782.

Jahr, K.J. \& G.E. Crow (2005). Floristic reevaluation of created wetlands in Portsmouth. New Hamsphire, Rhodora Publication 107: 87-102.

Jana, S., T. Bhattacharya, P.R. Pahari \& T.K. Dutta (2009). Diversity and community structure of aquatic insects in a pond in Midnapore town, West Bengal, India. Journal of Environmental Biology 30(2): 283-287.

Jansson, A. (1987). Micronectinae (Heteroptera, Corixidae) as indicators of water quality in Lake Vesijaervi, southern Finland, during the period of 1976-1986. Biological Research Report of the University of Jyvaskyla, 10: 119128.

Kalita, G (2008). Ecology \& Distribution of macroinvertebrate enmeshed fauna in Deepar wetland of Assam, India. PhD Thesis. Gauhati University, Guwahati, Assam, India.

Laskar, H.S. \& S. Gupta (2009). Phytoplankton diversity and dynamics of Chatla floodplain lake, Barak Valley, 
Assam, North East India-A seasonal study. Journal of Environmental Biology 30(6): 1007-1012.

Lenat, D.R., L.A. Smock \& D.L. Penrose (1980). Use of benthic macro invertebrates as indicators of environmental quality, pp. 97-114. In : Douglass, L.W. (ed). Biological Monitoring for Environmental Effects. Lexington books, Toronto.

Ludwig, J.A. \& J.F. Reynolds (1988). Statistical Ecology. A Primer on Methods and Computing. Wiely-Interscience Publication, John Wiley \& Sons, New York, 337pp.

Mackie, G.L. (2001). Applied Aquatic Ecosystem Concepts. Kendall/Hunt Publishing Company, xxv+744pp.

Majumdar, T.N. \& A. Gupta (2004). Aquatic insects in the lentic systems of North Cachar Hills, Assam, India. Journal of Current Science 5: 219-224.

McCafferty, W.P. (1981). Aquatic Entomology. The Fisherman's and Ecologists' Illustrated Guide to Insects and Their Relatives. Science Books International, Boston, Massachusetts, 448pp.

Moss, B. (1980). Ecology of Fresh Waters. Blackwell Scientific Publications, Oxford, 332pp.

Mulhouse, J.M. \& S.M. Galatowitch (2003). Revegetation of prairie pothole wetlands in the mid-continental V.S: 12 years post- reflooding. Plant Ecology 169: 143-59.

Narayan, R., K.K. Saxena \& S. Chauhan (2007). Limnological investigation of Texi Temple Pond in district Etawah (U.P.). Journal of Environmental Biology 28(1): 155-157.

Papacek, M. (2001). Small aquatic and ripicolous bugs (Heteroptera: Nepomorpha) as predators and prey: The question of economic importance. European Journal of Entomology 98: 1-12.

Ravera, O. (2001). A comparison between diversity, similarity and biotic indices applied to the macroinvertebrate community of a small stream: the Revella River (Como Province, Northern Italy). Aquatic Ecology 35: 97-107.

Sandin, L. \& R.K. Johnson (2000). The Statistical power of selected indicator metrics using macroinvertebrates for assessing acidification and eutrophication of running waters. Hydrobiologia 422/423: 233-243.

Singhal, R.N., Swaranjeet \& R.W. Davies (1986). The physicochemical environment and the plankton of managed ponds in Haryana, India. Proceedings of Indian Academy of Animal Sciences 95: 353-364

Subramanian, K.A. \& K.G. Sivaramakrishnan (2007). Aquatic Insects for Biomonitoring Fresh Water Ecosystems: A Methodology Manual. Trust for Ecology and Environment (ATREE), Bangalore, India, 31pp.

Thirumalai, G. (1994). Aquatic and semi-aquatic Hemiptera (Insects) of Tamilnadu-I, Dharampuri and Pudukkottai Districts. Occational Paper, Records of the Zoological survey of India 165: 4-40.

Thirumalai, G. (2007). A synoptic list of Nepomorpha (Hemiptera: Heteroptera) from India. Records of Zoological Survey of India Occational Paper Number 273: 1-84.

Vinson, M.R. \& C.P. Hawkins (1998). Biodiversity of streams: variation at local, basin and regional scales. Annual review of Entomology 43: 271-293.

Wollmann, K. (2001). Corixidae (Hemiptera, Heteroptera) in an acidic mining lake with $\mathrm{pH}$ less than or equal to $\mathrm{E}$ in Lusatia, Germany. Hydrobiologia 433(3): 181-183.

ZSI (2004). State fauna series 10 : Fauna of Manipur (Part-2)Insects. Edited by the Director, Zoological Survey of India, Kolkata, India. 